\title{
MOLECULAR SUBTYPES OF COLORECTAL CANCER - BRIEF REVIEW
}

\author{
Sanja Kapitanović \\ Laboratory for Personalized Medicine, Division of Molecular Medicine \\ Ruđer Bošković Institute, Zagreb, Croatia
}

\begin{abstract}
Summary
Colorectal cancer (CRC) is one of the most common cancers and one of the leading causes of cancer death in the Western world. The majority of colorectal cancers arise in sporadic form. The disease arises from the accumulation of mutations in oncogenes, tumor suppressor genes and mismatch repair genes during progression from normal colon epithelium to adenoma and metastatic carcinoma. Colorectal Cancer Subtyping Consortium describes four consensus molecular subtypes (CMS) of CRC: CMS1 (14\%, microsatellite instability, immune, strong immune activation), CMS2 (37\%, canonical, WNT and MYC signaling activation), CMS3 (13\%, metabolic, epithelial and metabolic dysregulation) and CMS4 (23\%, mesenchymal, transforming growth factor- $\beta$ activation), while $13 \%$ of colorectal cancers remained mixed or "unclassified".

This mini review will give some information about the most frequent molecular genetics changes in colorectal cancer and its molecular classification in four CMS subtypes due to its morphology, gene expression profile, somatic mutations and microsatellite instability.
\end{abstract}

Keywords: colorectal cancer; CMS classification; consensus molecular subtypes (CMS).

Colorectal cancer (CRC) is one of the most common cancers and represents the third most diagnosed cancer in men and the second most common cancer in women. Despite advances in surgery, chemotherapy and screening it is still one of the leading causes of cancer related death in the Western world [1].

Of all human cancers, the molecular genetic alterations in colorectal cancer are best understood. The disease arises from the accumulation of mutations in oncogenes, tumor suppressor genes and mismatch repair (MMR) genes during progression from normal colorectal epithelium to adenoma and metastatic carcinoma [2]. Colorectal cancer is a genetic disease that might be influenced by the 
local colorectal environment, individuals's genetic profile as well as by hereditary germline mutations $[3,4]$.

The majority of colorectal cancers (75-80\%) are sporadic, while around 20$25 \%$ of CRC have a hereditary component. However, only $5 \%$ of CRC arise due to high risk hereditary syndromes, such as Lynch Syndrome (LS) (3-5\%) and familial adenomatous polyposis (1\%) while the remaining CRCs have a positive family history but cannot be categorized to any hereditary CRC syndrome. These familial CRC are caused by single nucleotide polymorphisms (SNP) in less penetrant genes such as cytokines. Many susceptibility loci have been identified, however, their value in CRC risk prediction remains low [5-7].

Colorectal cancer is not a homogenous disease and can be classified in different subtypes which are characterized by specific molecular and morphological alterations. A major feature of colorectal cancer is genetic instability that can arise by at least two different mechanisms. According to The Cancer Genome Atlas (TCGA) the most CRC (around $84 \%$ of sporadic CRC) is characterized by chromosomal instability (CIN), with changes in chromosome number and structure including large deletions, gains, translocations and other chromosomal rearrangements. These molecular changes are described as a high frequency of DNA somatic copy number alterations (SCNA) and represent a hallmark of most tumors that arise by adenoma-carcinoma sequence [3,5,8-11]. Molecular genetic studies have associated CIN with activation of oncogenes (KRAS, PIK3CA) and inactivation of tumor suppressor genes (APC, SMAD4 and TP53) which go along with adenoma carcinoma sequence as it was first described by Fearon and Vogelstein in 1990 [7]. The second group (13-16\% of sporadic CRC) is hypermutated tumors. The etiology of hypermutated tumors is largely driven by the presence of microsatellite instability (MSI) due to defective DNA mismatch repair (MMR), specifically somatic hypermethylation of hMLH1 gene, one of the MMR genes as well as BRAF gene mutations [3,12-16]. The ultramutated colorectal cancers ( $3 \%$ of sporadic $\mathrm{CRC}$ ) have an extremely high mutation rate due to the presence of a mutation that inactivates the proofreading function within the exonuclease domain of the DNA replicating enzyme POLE (encoding DNA polymerase e), or rarely of POLD1 (encoding DNA polymerase d1). Ultramutated tumors are microsatellite stable and do not exhibit loss of expression of MMR proteins [12,17].

Early attempts at gene expression profiling in order to stratify colorectal cancer were made by several groups, but showed little agreement with each other, suggesting different number of categories, and did not lead to a useful classification system $[18,19]$. Subsequently, an international expert consortium 
(Colorectal Cancer Subtyping Consortium, CCSC) reached an agreement that describes four consensus molecular subtypes (CMS) after analysis of 18 different CRC gene expression datasets of more than 4000 samples. Approximately $87 \%$ of the 4151 samples that were analyzed by six expert groups were subclassified in 4 consensus molecular subtypes (CMS) while $13 \%$ of colorectal cancers remained mixed or "unclassified". These samples with mixed features possibly represent either a transition phenotype or intratumoral heterogeneity. Additional molecular data, including mutations, SCNAs, promoter methylation status, and post-translational gene regulation, as well as biological characteristics were correlated with the subtypes $[18,20,21]$, (Table 1).

Table 1. Consensus molecular subtypes of colorectal cancer [20,21]

\begin{tabular}{|c|c|c|c|}
\hline CMS1 & CMS2 & CMS2 & CMS4 \\
\hline $14 \%$ & $37 \%$ & $13 \%$ & $23 \%$ \\
\hline $\begin{array}{l}\text { Microsatellite } \\
\text { instability - } \\
\text { Immune }\end{array}$ & Canonical & Metabolic & Mesenchymal \\
\hline $\begin{array}{l}\text { Hypermutated } \\
\text { Microsatellite } \\
\text { unstable (MSI) }\end{array}$ & $\begin{array}{l}\text { Epithelial } \\
\text { WNT and MYC } \\
\text { signaling activation } \\
\text { SCNA high }\end{array}$ & $\begin{array}{l}\text { MSI status mixed } \\
\text { SCNA low } \\
\text { Metabolic } \\
\text { dysregulation } \\
\end{array}$ & $\begin{array}{l}\text { TGF- } \beta \text { activation } \\
\text { SCNA high } \\
\text { Mesenchymal } \\
\text { transition }\end{array}$ \\
\hline High methylation & Low methylation & \begin{tabular}{|l} 
Moderate \\
methylation
\end{tabular} & Low methylation \\
\hline BRAF mutations & & KRAS mutations & \\
\hline $\begin{array}{l}\text { Immune infiltration } \\
\text { and activation } \\
\text { Adaptive immune } \\
\text { response }\end{array}$ & Poorly imunogenic & Poorly imunogenic & $\begin{array}{l}\text { Stromal infiltration } \\
\text { Innate immune } \\
\text { response } \\
\text { Immunosuppresion } \\
\text { Complement } \\
\text { activation }\end{array}$ \\
\hline Proximal colon & Distal colon & Mixed & Distal colon \\
\hline $\begin{array}{l}\text { Worse survival } \\
\text { after relapse }\end{array}$ & & & $\begin{array}{l}\text { Worse relapse-free } \\
\text { and overall survival }\end{array}$ \\
\hline
\end{tabular}


CMS1 (MSI-immune, $14 \%$ ) CRC are hypermutated due to defective DNA mismatch repair with microsatellite instability (MSI) and MLH1 expression silencing, high methylation (CpG island methylator phenotype, CIMP-high), frequent BRAF mutations and low SCNAs. This molecular subtype is in accordance with the previously well-characterized sporadic MSI CRC subgroup. Gene expression profiling revealed evidence of strong immune activation (immune response, PD1 activation, NK cell, Th1 cell and cytotoxic T cell infiltration) in CMS1, consistent with pathological descriptions of prominent tumor-infiltrating CD8 ${ }^{+}$ cytotoxic T lymphocytes [18]. Patients with early stage MSI (CMS1) tumors have a better prognosis compared to patients with microsatellite stable (MSS) tumors. CMS1 have a good prognosis when detected before disease dissemination, in part, due to the presence of specific T-cell populations and natural killer cells. However, patients with the CMS1 tumors, which are more prevalent in the right colon, had a very poor survival rate after relapse [21].

The majority of colorectal cancers previously described as chromosomal instability (CIN) are split in three subgroups based on transcriptomic profiling, but all three groups of tumors were characterized by high levels of SCNAs [18,22].

Colorectal cancer in the CMS2 (canonical, 37\%) subgroup arises from the canonical adenoma-to-carcinoma sequence including APC, KRAS and p53 gene mutations [7]. CMS2 CRC predominantly displayed a differentiated epithelial cell phenotype with prominent WNT- $\beta$ catenin and MYC signaling activation. CMS2 cancers are more commonly left sided lesions (59\%) and with highest five-year overall survival for all stages compared with colorectal cancers of other CMS subtypes [21].

The CMS3 (metabolic, 13\%) subtype have fewer SCNAs and contain more MSI/hypermutated tumors than CMS2 and CMS4. Although KRAS mutations are present in all molecular subtypes, they are more prevalent in CMS3 CRC (in 68\%). Gene expression analysis of CMS3 found predominantly epithelial signatures and evidence of metabolic dysregulation in a metabolic pathways, including glutamine, fatty acid, and lysophospholipid metabolism [18,20,21]. For metastic colorectal cancer, the higher frequency of KRAS mutations in CMS3 tumors is an indicator of poor response to epidermal growth factor receptor (EGFR) monoclonal antibodies. In those tumors that are not positive to KRAS, BRAF or PIK3CA mutations, anti EGFR monoclonal antibodies may be useful $[3,21]$. Since the reprogramming of cellular metabolism is an established hallmark of cancer, preclinical studies have shown efficacy using inhibitors that target many metabolic processes, such as glucose transporters, glycolytic enzymes 
and fatty acid synthase. These inhibitors may prove to be a useful treatment in KRAS mutant CRC [22-24].

CMS4 tumors (mesenchymal, 23\%) show increased expression of epithelial to mesenchymal transition (EMT) genes and evidence of prominent transforming growth factor- $\beta$ activation, with expression of genes involved in complement-associated inflammation, matrix remodeling, stromal invasion and angiogenesis. CMS4 tumors exhibit very low levels of hypermutation, MSS status, and very high SCNA level. CRC of CMS4 subtype display a mesenchymal phenotype and an inflammatory microenvironment with prominent innate immune cells [20]. The level and nature of inflammation in primary CRC may be complex, but the type, density and intratumor location of immune cells can predict patient survival, often better than classical staging [25]. In the contrast to the anti-tumor immune environment of CMS1 cancers, the CMS4 tumor microenvironment is proinflammatory, with the presence of Treg cells, T helper 17 cells, myeloid-derived suppressor cells, and tumor promoting macrophages. Patients with the CMS4 subtype, often diagnosed at advanced stages, had worse overall survival and worse relapse-free survival than patients in other CMS groups $[18,21,22]$.

CMS classification system has been suggested by authors (Colorectal Cancer Subtyping Consortium) to be the most robust classification system currently available for CRC based on biological processes related to gene expression profiles and is suggested as a basis for clinical stratification in trials and other studies with potential for subtype-based targeted therapy [20,22].

Modern molecular platforms give the ability to characterize tumors at multiple levels and to define molecular and biological subtypes of cancer. Cancers could be divided into subtypes that are more or less aggressive. Identification of a more aggressive subtype may influence the type of their treatment. Molecular stratification and subclassification of tumors will add a step to traditional clinical practice and better diagnosis and therapy of different types of cancer as well as colorectal cancer [26].

Integration of wide-ranging molecular data has generated two systems of classification of colorectal cancers: TCGA classification [12] and CMS classification $[20,22]$. Both classifications have been proposed to allow better prognostication and are potentially important for future use in clinical trials and for multidisciplinary team discussions in oncology. All these results, and both classification systems are a welcome step toward translating research findings to the clinicians but many more steps including optimization of molecular genetic testing are needed for clinical application. 


\section{References}

[1] Kinzler, KW, Vogelstein B. Lessons from hereditary colorectal cancer. Cell. 1996;87: 159-70.

[2] Vogelstein B, Kinzler KW. Cancer genes and the pathways they control. Nat Med. 2004;10:789-99. doi:10.1038/nm1087

[3] Carethers JM, Jung BH. Genetics and genetic biomarkers in sporadic colorectal cancer. Gastroenterology. 2015;149:1177-90. doi: 10.1053/j.gastro.2015.06.047

[4] Stoffel EM, Boland CR. Genetics and genetic testing in hereditary colorectal cancer. Gastroenterology. 2015;149:1191-203. doi: 10.1053/j.gastro.2015.07.021

[5] Migliore L, Migheli F, Spisni R, Coppede F. Genetics, cytogenetics and epigenetics of colorectal cancer. J Biomed Biotech.2011; Article ID 792362. doi:10.1155/2011/792362

[6] Jasperson KW, Tuohy TM, Neklason DW, Burt RW. Hereditary and familial colon cancer. Gastroenterology. 2010;138:2044-58. doi: 10.1053/j.gastro.2010.01.054.

[7] Cohen SA, Leininger A. The geetic basis of Lynch syndrome and its implications for clinical practice and risk management. Appl Clin Genet. 2014;7:147-58. doi: 10.2147/ TACG.S51483

[8] Fearon ER, Vogelstein B. A genetic model for colorectal tumorigenesis. Cell. 1990;61: 759-67.

[9] Berg M, Soreide K. Genetic and epigenetic traits as biomarkers in colorectal cancer. Int J Mol Sci. 2011;12:9426-39. doi:10.3390/ijms12129426

[10] Pritchard CC, Grady WM. Colorectal cancer molecular biology moves into clinical practice. Gut. 2011;60:116-29. doi: 10.1136/gut.2009.206250.

[11] Poulogiannis G, Ichimura KI, Hamoudi RA, Luo F, Leung SY, Yuen ST, et al. Prognostic relevance of DNA copy number changes in colorectal cancer. J Pathol. 2010;220:338-47. doi: 10.1002/path.2640

[12] Cancer Genome Atlas Network. Comprehensive molecular characterization of human colon and rectal cancer. Nature. 2012;487:330-7. doi:10.1038/nature11252

[13] Fearon ER. Molecular genetics of colorectal cancer. Annu Rev Pathol. 2011;6:479-507. doi: 10.1146/annurev-pathol-011110-130235.

[14] Grady WM, Carethers JM. Genomic and epigenetic instability in colorectal pathogenesis. Gastroenterology.2008; 135:1079-99. doi:10.1053/j.gastro.2008.07.076

[15] Umar A, Boland CR, Terdiman JP, Syngal S, de Chapelle A, Rushoff J, et al. Revised Bethesda guidelines for hereditary nonpolyposis colorectal cancer (Lynch syndrome) and microsatellite instability. J Natl Cancer Inst. 2004;96:261-8. doi: 10.1093/ jnci/djh034

[16] Heinimann K. Toward a molecular classification of colorectal cancer: the role of microsatellite instability status. Frontiers Oncol. 2013;3:272. doi:10.3389/fonc.2013.00272

[17] Palles C, Cazier JB, Howarth KM, Domingo E, Jones AM, Broderick P, et al. Germline mutations affecting the proofreading domains of POLE and POLD1 predispose to colorectal adenomas and carcinomas. Nat Genet. 2013;45:136-44. doi:10.1038/ng.2503 
[18] Muller MF, Ibrahim AEK, Arends MJ. Molecular pathological classification of colorectal cancer. Virchows Arch. 2016;469:125-34. doi: 10.1007/s00428-016-1956-3

[19] Budinska E, Popovici V, Tejpar S, D’Ario G, Lapique N, Sikora KO, et al. Gene expression patterns unveil a new level of molecular heterogeneity in colorectal cancer. J Pathol. 2013;231:63-76. doi: 10.1002/path.4212

[20] Guinney J, Dienstmann R, Wang X, de Reynies A, Schlicker A, Soneson C, et al. The consensus molecular subtypes of colorectal cancer. Nature Med. 2015;21:1350-6. doi: 10.1038/nm.3967

[21] Thanki K, Nicholls ME, Gomez G, Gajjar A, Senagore AJ, Rashidi L, et al. Consensus molecular subtypes of colorectal cancer and their clinical implications. Int Biol Biomed J. 2017;3:105-11.

[22] Dienstmann R, Vermeulen L, Guinney J, Kopetz S, Tejpar S, Tabernero J. Consensus molecular subtypes and the evolution of precision medicine in colorectal cancer. Nature Rev Cancer. 2017;17:79-92. doi: 10.1038/nrc.2016.126.

[23] Hanahan D, Weinberg RA. Hallmarks of cancer: the next generation. Cell. 2011;144: 646-74. doi: 10.1016/j.cell.2011.02.013.

[24] Zhao Y, Butler EB, Tan M. Targeting cellular metabolism to improve cancer therapeutics. Cell Death Dis. 2013;4: e532. doi: 10.1038/cddis.2013.60.

[25] Galon J, Costes A, Sanchez-Cabo F, Kirilovsky A, Mlecnik B, Lagorce-pages C, et al. Type, density, and location of immune cells within human colorectal tumors predict clinical outcome. Science. 2006;313:1960-4. doi: 10.1126/science.1129139

[26] Ogino S, Fuchs CS, Giovannucci E. How many molecular subtypes. Implications of the unique tumor principle in personalized medicine. Expert Rev Mol Diagn. 2012;12:621-8. doi: 10.1586/erm.12.46. 
Sažetak

\section{Molekularni podtipovi kolorektalnog karcinoma - kratki pregled}

Kolorektalni karcinom je jedan od najčešćih zloćudnih tumora i jedan od vodećih uzroka smrti od raka u zemljama razvijenog svijeta, a najčešće se javlja u sporadičnom obliku. Ovaj zloćudni tumor nastaje kroz duži niz godina tijekom kojih kao posljedica mutacija u onkogenima, tumor supresorskim genima i genima za popravak DNA iz normalne sluznice kolona preko adenoma nastaje zloćudni metastatski karcinom. Nova CMS (od engl. Consensus Molecular Subtypes) klasifikacija dijeli karcinome kolorektuma na četiri CMS podtipa: CMS1 (14\%, pozitivni na mikrosatelitnu nestabilnost, jaka imunološka infiltracija tumora), CMS2 (37\%, epitelni koji slijede adenom-karcinom slijed, aktivacija Wnt te Myc signalnog puta), CMS3 (13\%, metabolički, epitelni s metaboličkom disregulacijom) te CMS4 (23\%, mezenhimalni, jaka imunološka infiltracija strome, aktivacija TGF- $\beta$ signalnog puta) dok $13 \%$ tumora ostaje neklasificirano odnosno miješanog podtipa.

$\cup$ ovom kratkom preglednom radu opisane su molekularno genetičke promjene u karcinomima kolorektuma te molekularna klasifikacija ovog zloćudnog tumora na molekularne (CMS) podtipove s obzirom na morfologiju, transkriptomski profil, stečene mutacije i mikrosatelitnu nestabilnost.

Ključne riječi: karcinom kolorektuma; CMS klasifikacija; CMS molekularni podtipovi.

Corresponding author:

Sanja Kapitanović

e-mail: kapitan@irb.hr 